\title{
The moral panic about the socializing of young people in Minangkabau
}

\author{
LYN PARKER
}

\begin{abstract}
This paper analyses the discourse surrounding the perceived threat of free seks and pergaulan bebas (free socializing) to the moral health of young Minangkabau people, and in particular, young women, in West Sumatra. It uses the sociological frame of "moral panic" to examine contemporary discussions about globalization and the influence of "the West" in West Sumatra. The paper examines the way in which "the authorities" in West Sumatra (media, such as teen magazines and newspapers, academics, government and law, teachers, and community leaders) present the threat, and the way in which young people, who are the target of the moral panic onslaught, see themselves in relation to the threat. I argue that, unlike the original "folk devils" of the moral panics in Britain, young people in Minangkabau broadly give their consent to the authorities, displaying a striking commitment to social conservatism, local culture, and Islamic values.

KEYWORDS

Moral panic, West Sumatra, Minangkabau, Indonesia, youth, sexuality, free sex, free socializing.
\end{abstract}

The term "moral panic" was adopted by Cohen (1972) in his book, Folk devils and moral panics; The creation of the Mods and Rockers, to refer to the creation of a mass panic about deviant youth by the mass media in the United Kingdom in the late 1960s. In this paper, I discuss the way in which "the authorities" in West Sumatra and Indonesia (media, such as teen magazines and newspapers, academics, government and law, teachers, community leaders), present the threat and the way in which young people, who are the target of the moral panic onslaught, see the "crisis", behave, and position themselves in relation to the perceived threat. I argue that unlike the "folk devils" of the moral panics in Britain, young people in Minangkabau broadly give their consent to the

LYN PARKER is an anthropologist and Professor in Asian Studies at the University of Western Australia. Her published work includes From subjects to citizens; Balinese villagers in the Indonesian Nation-State (2003), The agency of women in Asia (2005), Women and work in Indonesia (2008, with Michelle Ford) and Adolescents in contemporary Indonesia (in press, with Pam Nilan). She has specialized in the anthropology of Indonesia and is currently conducting research on environmentalism, adolescence and women, education, citizenship, multiculturalism and religion, mainly in West Sumatra and Bali. Lyn Parker may be contacted at: lyn.parker@uwa.edu.au.

(C) 2014 Faculty of Humanities, University of Indonesia 
authorities, displaying a striking commitment to social conservatism, local culture, and Islamic values.

The research on which this paper is based was conducted from 2004 to 2011. Apart from critical reading of the literature on the Minangkabau, Islam, and youth in Indonesia, the paper draws on ethnographic fieldwork conducted in highland West Sumatra intermittently since 2004. During the fieldwork, I read the local daily newspapers, magazines, school textbooks, and other relevant primary source material; conducted hundreds of interviews with students and other youth, parents, teachers, and community leaders; held several focus group discussions with young people; conducted participant observation of family, community and school life, and of events such as pop concerts and weddings; and conducted a large team survey.

The paper is divided into three sections: it begins by introducing the sociological understanding of the term "moral panic", then examines the discourse of "the authorities", and then explores how young people perceive the moral threat posed by the influx of supposedly Western sexual mores.

\section{MORAL PANICS}

The term "moral panic" was developed by Cohen (1972) to refer to the creation of a mass panic about deviant youth by the mass media.

Societies appear to be subject, every now and then, to periods of moral panic. A condition, episode, person or group of persons emerges to become defined as a threat to societal values and interests; its nature is presented in a stylized and stereotypical fashion by the mass media; the moral barricades are manned [sic] by editors, bishops, politicians, and other right-thinking people; socially accredited experts pronounce their diagnoses and solutions; ways of coping are evolved or (more often) resorted to; the condition then disappears, submerges or deteriorates and becomes more visible. Sometimes the object of the panic is quite novel and at other times it is something which has been in existence long enough, but suddenly appears in the limelight (Cohen 2004: 1).

Another classic text, Policing the crisis, emphasizes the role of "the authorities" in constructing a moral panic:

When the official reaction to a person, groups of person, or series of events is out of all proportion to the actual threat offered, when "expert", in the form of police chiefs, the judiciary, politicians, and editors perceive the threat in all but identical terms, and appear to talk "with one voice" of rates, diagnoses, prognoses, and solutions, when the media representations universally stress "sudden and dramatic" increases (in numbers involved or events) and "novelty" above and beyond that which a sober, realistic appraisal could sustain, then we believe it is appropriate to speak of [...] a moral panic (Hall et al. 1978: 16).

In these works, the moral panic acts "on behalf of the dominant social order" (McRobbie and Thornton 1995: 562). These studies show how the media in particular galvanizes public opinion through sensationalist and emotive 
language, such that the public demands that "something be done about it": not uncommonly, the police are required to act, sometimes governments even react with new legislation. Sometimes a past reminiscing of social order, when youth were well behaved and polite, is nostalgically invoked. The threat of social disintegration hovers.

Hall et al. (1978) showed that the moral panic was actually not an isolated incident: using Gramsci's notion of hegemony, they showed how the moral panic acted as an early warning system, providing a trigger for the dominant ideological system to do more work, amplifying the local "problem" to national proportions, naturalizing stronger social control, and enlarging the space for more insidious forces.

The term became very popular among sociologists and journalists (McRobbie and Thornton 1995: 559-560); its overuse led to fuzziness and consequently reduced its usefulness as an analytic tool. In 1995, McRobbie and Thornton argued that the phenomenon had changed:

Moral panics, once the unintended outcome of journalistic practice, seem to have become a goal. Rather than periods to which societies are subject "every now and then" (Cohen 1972/80: 9), moral panics have become the way in which daily events are brought to the attention of the public. They are a standard response, a familiar, sometimes weary, even ridiculous rhetoric rather than an exceptional emergency intervention. Used by politicians to orchestrate consent, by business to promote sales in certain niche markets, and by media to make home and social affairs newsworthy, moral panics are constructed on a daily basis.

McRobbie and Thornton argue, presumably with regard to the United Kingdom, that not only has the mediascape become more complex, but also society is more heterogeneous and less consensual than the moral panic literature assumes. For instance, they argue that the moral panic scholars neglect youth as a distinct category within society; they argue that the youth of the 1990s look back fondly to a past, but it is a past of youth transgression and rebellion that is valorised, not a conservative social order. Audience reception of the moral panic message can no longer be assumed.

Moral panics act in service of the authorities in society, who identify the aberrant "folk devils". The "devils" are construed as a threat to the morality of society, and its value system. Cohen, building on Hall et al., notes that "successful moral panics owe their appeal to their ability to find points of resonance with wider anxieties" (2004: xxx). This aspect - broader or deeper resonance - can be illustrated with the current moral panic about paedophile sex offenders. Garland notes that it "seems to be connected to unconscious guilt about negligent parenting and widespread ambivalence about the sexualisation of modern culture" - and of girls (2008: 15). There is thus a psychoanalytical (Freudian) aspect to the moral panic: society can project onto the "devils" its sentiments of guilt and ambivalence, about which it is probably in denial. The other dimension of the moral panic that seems quite Freudian is that it is indeed a panic - an hysterical or neurotic reaction, characterised by frenetic excitement and "collective effervescence" (Garland 2008: 15). 


\section{THE MORAL PANIC OF “THE AUTHORITIES”}

In Indonesia, the discourse of "the authorities" elaborates on the perception that morality is "rotting" and that young people are vulnerable to the influence of global popular culture and the sexual immorality of the West. This discourse is nationwide, but in West Sumatra, the discourse is particularly anxious and strident. It explicitly links the decline of morality to the decline of Minangkabau ethnic identity and culture, and advocates greater Islamic piety as the solution.

There are some keywords that crop up repeatedly in this discourse: the need to "filter" modernity, to stem the rotting or deterioration of the moral fibre, and to strengthen the "fortress" of morality. Here is a short excerpt from the book, Moralitas Politik Muhammadiyah (Muhammadiyah Political Morality), by Amien Rais, former Speaker of the People's Assembly and leader of the Partai Amanat Nasional (PAN), National Mandate Party, which dominates in West Sumatra:

Vying for Indonesia's adolescents is a long-term obligation of Islamic teaching. Our children and adolescents are an invaluable asset. We have to save them from the erosion of faith caused by the invasion of non-Islamic values which seep into the heart of various Islamic communities in Indonesia. If our children and adolescents have a strong fortress (al-hususn al hamidiyyah) in this era of globalization and information, if God is willing, then our future will stay pure (cited in Harding 2008: par. 6). ${ }^{1}$

As Harding notes,

Words such as "seep" and "invasion" in the above quotation refer to globalisation as an uninvited, unwelcome and menacing force that threatens to take over local cultural and religious values. The battle imagery used to describe the destructive nature of globalisation implies that it is a form of war in which adolescents and Indonesians in general must be prepared to fight (2008: par. 6).

In the following section, I survey some of the mass media messages with regard to the moral panic on sex, then turn to academic books, the government response, and the discourse of teachers and community leaders.

\section{MAGAZINES}

The glossy magazines that target teenage girls - magazines like Aneka Yess, Kawanku (My Friend), and Gadis (Girls) - present adolescents as a distinct, modern social group. These magazines are quite expensive, ${ }^{2}$ and present a life of comparative luxury and ease. They present adolescence as a fun, breezy

1 See RB. Khatib Pahlawan Kayo. 2003. "Problematika dakwah masa kini", Majalah Tabligh, Dakwah Khusus 1(12). [Http:/ / www.seasite.niu.edu/trans/Indonesian/Concordance/ Situs\%20Persyarikatan\%20Muhammadiyah\%20 Indonesia-Khatib.htm.]

2 However, there is a thriving market in second-hand magazines, and each magazine that is bought is read or looked at by many people. 
time: the magazines are bright and glossy, the colours saturated; the girl models are always smiling and having fun; overall, adolescence is a time of cheerfulness and childishness. Indonesian female adolescents are represented as innocent and naïve; therefore, they must be protected from the immoral influence of the West, which is assumed.

Handajani conducted an excellent study of these magazines and concluded:

The result of this contradictory representation is a unique group of female adolescents who live in a world of their own. They are supposed to emulate the appearance of western pop idols, but at the same time uphold values of chastity and virginity. The magazines therefore develop a unique adolescent identity but not an empowering one, because this representation places adolescents within a selectively protective bubble. This bubble shields adolescents from the real dangers in society that are related to their gender and sexuality. However, this bubble is not at all protective with regards to a consumerism that capitalizes on "modern" western body images (Handajani 2005: v).

Examination of the senior high school curricula shows that sex education is not part of the school curriculum, except as part of a biology lesson about human reproduction (and many students do not take biology). Most teenage girls learned about sex through glossy magazines. However, most admitted that their knowledge was inadequate. It was astonishing that most girls said that they had not known about menstruation before it happened to them.

As Handajani has shown, girls' magazines do not teach realistically about sex. They do provide the odd dry anatomy lesson, but the emphasis is on moralizing:

Sexuality in girls' magazines is discussed most of the time in terms of prevention of and caution against the lure of premarital sex. In girls' magazines, sex education is about providing moral guidance with regards to appropriate female sexuality. It is full of messages about morality. In contrast, sex education in Hai boys' magazine is about responding to the curious nature of boys who want to know more about their sexual organs and their function (Handajani 2005: 133).

The sexual discourse in girls' magazines is therefore frequently dissociated from the body and always tied in some way to its social and spiritual (religious) meanings:

"If you think about it, it doesn't make any sense, does it, how can a baby pass through such a small opening like the vagina?" asked Chica in amazement.

"That is the Glory of God, Cha." (Handajani 2005: 135)

Since 2004, girls in West Sumatra have been increasingly buying Islamic magazines and novels. The most popular magazine among my informants was the decidedly less glossy and less colourful magazine, Annida. It was interesting to watch how this magazine changed: it began life in 1991 as a drab, unexciting small publication, with cover pictures usually of a very pious-looking young woman, sitting in silhouette, praying in full Islamic 
attire; it became larger, glossy and with fun covers showing young women in trendy Muslim fashion, with pretty full-face models grinning, and topics announced in trendy bahasa gaul (youth slang) and English. It combines coolness with dakwah (Islamic evangelization) as evident in its motto from 2003 to 2008: Cerdas, Gaul, Syar'i (Smart, trendy, and pious). It can be quite political too, for example, its February-March 2006 issue had in big yellow letters on its front cover: POKOKNYA TOLAK PORNOGRAFI \& PORNOAKSI (No matter what, reject pornography and porn acts), with a splash of " $100 \%$ ANTI PORNOGRAFI". However, readers like the short stories, advice columns, and the Islamic fashion - gaul dan gaya 'cool and stylish' (Kailani 2010).

\section{NEWSPAPERS}

Study of the newspapers in this period shows an abiding preoccupation with youth sexuality: it was evident that a combination of newly free media and Islamic revival had produced a national frisson about sex. The draft AntiPornography and Pornographic Acts Bill (RUU APP), originally drafted in 1992 and squashed then, was revived in 2006. Parliamentary and media discussions triggered huge street demonstrations in opposition to, and even larger demonstrations in support of, censorship. The new Law, passed in 2008, made it an offence to kiss in public or display "sensual body parts", such as women's breasts, navel, hips, and thighs. Supporters said that it was needed to protect the innocence of Indonesian children and teenagers from negative foreign influences, particularly "western" influences. These and other nationwide sexuality issues, such as the publication of Indonesia's first issue of Playboy magazine, Indonesia's first gay film, and the government initiative to install condom vending machines in some public places, are part of the national context of the moral panic in West Sumatra from 2004. In contemporary Indonesia, sexuality is always a moral discourse, and public authorities feel that they have to take a prohibitive and protectionist stance.

Of course, newspapers and other media know that "sex sells" and that creating a moral panic has become a goal (McRobbie and Thornton 1995). Newspapers published in West Sumatra not only joined the national frisson about illicit sex: they linked illicit sexual acts (even kissing and hugging) to immorality and foreign culture, and to a loss of ethnic integrity, usually by citing scholars and elected political leaders. For instance, the Mayor's Office of Bukittinggi banned the celebration of Valentine's Day in 2008 and following years. The news spread as far as the Jakarta Post. The Deputy Mayor argued that

Valentine's Day celebration is not our culture as it usually relates closely to immoral acts where, during the celebration, young couples tend to hug and even kiss each other. This is an immoral act, right? He urged parents not to let their sons and daughters go out that night and instead urged schools to have their students attend mosques to listen to sermons "for the sake of improving their morality" (Bachyul 2008).

The theme was the same in the reporting of Valentine's Day, 2012. The Head 
of the Civil Police for Bukittinggi justified the "netting" of 17 people (4 men and 13 women), saying:

Valentine merupakan budaya asing yang telah menjadi momen penting bagi kalangan generasi muda dewasa ini termasuk di kota Bukittinggi. Dengan memanfaatkan momen itu secara berlebihan, menyebabkan terjadinya tindakan asusila yang melanggar norma agama dan adat istiadat (Padang Ekspres 2012).

(Valentine's is foreign culture. It is already become an important moment for the young generation today, also in Bukittinggi. By exploiting this moment excessively, it causes immoral behaviour that violates the norms of religion and customs.)

Some newspaper articles reported in a sensationalist (and irresponsible) manner on the national slide into youth sexual immorality, for example "KRR Survey Results: 63 percent of teenagers have had sex" (Singgalang 30 July 2010). This article presented the results of a national survey, but neglected to tell us the number of respondents; it also presented internally inconsistent figures: in the title, " $21 \%$ of teens in SMP (junior high school) and SMA (senior high school)" had had an abortion, but inside the article it was $27 \%$. Some newspaper reports were local and panicky, for example, "Condom found in student's schoolbag" (Singgalang 28 September 2004).

\section{ACADEMICS BOOKS}

Academic books joined the fray: titles include Masyarakat adat Minangkabau terancam punah (Minangkabau adat society threatened with extinction, Amir 2007), Erosi moralitas di Minangkabau (The erosion of morality in Minangkabau, At-Tubani 2005), Minangkabau di mata anak muda (Minangkabau in the eyes of young people, Ronidin 2006), Minangkabau di persimpangan generasi (Minangkabau at the crossroads of the generations, Putra 2007), Tiga menguak tabir; Perempuan Minangkabau di persimpangan jalan (Lifting the curtain; Minangkabau women at the crossroads, Naim 2006), and an edited collection of seminar papers Kebijakan setengah hati dan kerisauan tentang degradasi kebudayaan Minangkabau (Half-hearted policy and concerns about the degradation of Minangkabau culture, Herwandi 2007), published from papers presented at a seminar on "Retrospection, repositioning and the revitalisation of Minangkabau culture in an era of multiculturalism and globalisation" in 2004.

\section{GOVERNMENT AND LAW}

The national moral panic is at least partly a reaction to the unprecedented level of social and political change occurring in Indonesia. The freeing of the media from censorship and the incursions of global pop culture certainly "upped the ante" among conservative Muslims. On the political front, the downfall of Indonesia's "strong man" and the twin processes of democratization and decentralization almost certainly created both a power vacuum at the centre and unease and anxiety nationwide. 
In several regions, including West Sumatra, the response was to try to strengthen the practice of Islam through implementing syariah (Islamic law). This was done under the Regional Autonomy Laws No. 22/1999 and 25/1999. However, the legality of the Perda (Peraturan Daerah 'Regional Autonomy Law') that have been implemented in West Sumatra and elsewhere is dubious, because one area that was explicitly not decentralised under these laws is religion (for example, see Hooker 2008: 265). Hooker notes that the sole emphasis in "implementing syariah' is on conduct in public" (2008: x); others have noted that the burden of implementing syariah has fallen unfairly on women, who have had their mobility and clothing restricted (for instance Noerdin 2002).

Here we quote from some West Sumatran Perda, because they are unusually expansive in trying to justify the coercion involved in making people "better Muslims". In addition, they are explicit about the links among Islam, Minang adat and Minang cultural identity. These Perda have not gone uncontested: several observers have declared the regulations offensive, because religious commitment cannot be imposed "from above" - that it should "come from the heart", was an expression that several teenage girls used, in stating their opposition to the forced wearing of the jilbab (Islamic headscarf).

The elucidation of the "mother text" of the Perda in West Sumatra reads:

The prevention and eradication of immorality regulated by this Regulation includes various efforts to stem the outbreak of sinful acts, now often termed "social ills". Immoral behaviour in this region has begun to disturb society and disrupt the harmony of family and social life, and has undermined the foundation of Minangkabau social life, which is based on [the principle that] "Adat rests on Syariah, Syariah rests on the Scripture of God". If this matter is not speedily checked, it is feared that future generations will lose their culture: "Syariah legislates, Adat is used, Nature is the teacher" (Syarak mangato, Adat memakai, Alam takembang jadi guru). Thus the primary aim of this Regulation is to stem the decline in the morals of society in general, and of the coming generations in this region in particular. Thus the implementation of the Regulation consistently refers to religious teachings, adat norms, and the regulations and laws in force, so that the moral decline resulting from various forms of immoral acts will speedily be overcome. (Perda No.11/2001, Province of West Sumatra, cited in Hooker 2008: 269-270.

In Solok, the local government legislated that all schoolchildren and engaged couples had to be able to recite selected passages from the Qur'an (to a level appropriate to their age) (Perda No. 10/2001). If students cannot, they may not graduate to the next class nor graduate from school with the appropriate certificate; similarly, if both parties to a marriage cannot recite the selected Qur' an passages competently, the marriage may not take place. The elucidation of this Regulation explains:

[T] improve faith and piety in the community and create a harmonious and joyful community, it is necessary to implement regulations that will serve to motivate 
the community to improve its level of faith and piety by improving literacy in the Qur'an. It is expected that the implementation of the Regional Regulations will motivate school students and those engaged to be married to study the Qur' an and eventually to understand and practise the lessons correctly. (Perda No. 10/2001, District of Solok, cited in Hooker 2008: 273)

The regulations assume that laws can change behaviour, and that changed behaviour means enhanced religiosity. In fact, authorities of all sorts assume that heightened exposure to religious teachings and morality discourse will create better Muslims and hence cure the sick society. However, in these regulations there is a significant attempt not to cure but to prevent immorality, and the target audience is "the coming generations".

\section{TEACHERS}

Schools and teachers have a captive audience: young people spend a great deal of time at school, and there are many opportunities for teaching morality. Morals education flows through many subjects and many classes; teachers are unrelenting in their discrediting of a host of "outside influences" that are identified as the cause of "rotting" morals. Western films and television are easy targets.

For instance, a senior high school lesson in the subject "Indonesian language" was devoted to how to write paragraphs: it advocated using topic sentences and supporting sentences and conclusion. Students were asked to write a paragraph on a topic of their choice. The most commonly chosen topics were "Thinking about God's creation", "Western films", and "Living in a dormitory". A couple of students wrote about "Wearing Islamic clothes". The model paragraph on "Western films" that the teacher put together, with input from students after they had written their own paragraphs, began by saying that there are many opinions about the influence of television programs. The positive influences include education, especially the teaching of Indonesian and foreign languages, and the opportunity to learn about other ways of life and technology. The negative influences include drugs, free socializing, and not having respect for parents and older people. The result of all these negative influences is that "our morality and culture will decline". The paragraph concluded that the negative influences outweigh the positive ones. This division into the positive and negative influences of globalization was conventional: most teachers frequently acknowledged the advances in science and technology that the West had produced, and routinely identified the negatives as free sex and drugs (always assigned with "the West") and the loss of culture and morality. Students were told that they had to filter out the negatives, and accept and deploy the positives.

\section{COMMUNITY LEADERS}

As with the Perda that require students and engaged couples to be able to recite the Qur'an, the assumption is that constant exposure to "the right path" 
(jalan yang baik) and constant teaching about morality will protect young people from the pernicious influence of the West. Many people in authority think it is safer to pre-empt immoral behaviour than to "cure" it. Hence there is a strong discourse of "protection", particularly of young women. In adat teachings there is also a strong emphasis on the need to protect and supervise adolescent girls. Blackwood explains:

Because the future viability of the sublineage rests with the women, senior women (and elder brothers) carefully watch young women and make efforts to keep them within easy reach. Unmarried daughters are expected to be chaste, decorous, and modest, ideals encapsulated in the term malu. This expectation reflects Islamicist and adat ideals for young women (Blackwood 2000: 77-78).

Traditionally, post-pubescent girls were closely guarded and kept busy in the home; their forays into the fields and village were closely watched by those who had a vested interest in their good reputation and a good marriage. It was felt that "adolescent girls should not leave the house unaccompanied" (Whalley 1993: 67). Young women virtually never ventured outside of the family home at night. Parents, teachers, and community leaders explicitly link the protection of young women to the dangers of "free sex", explaining that if a girl got pregnant outside of marriage and there was no one to marry her, she would be "thrown away". Similarly, if a girl married the wrong person (for instance, a non-Minang or non-Muslim), she would be lost to the family and the survival of the family and lineage would be threatened. In this discourse of protection, seclusion, and supervision of adolescent girls, adat and Islam cannot be disentangled: the two agree on this. One senior lineage elder explained,

[T]eenage girls...who are called Puti Bungsu...are the baton to be passed on in the relay to build adat, to develop religion...[W]e Minangkabau yearn after our Puti Bungsu.

In religion it is said that women are the pillar of the nation. When they are good, everything is good. When they are rotten, everything is rotten. So adolescent girls have a heavy responsibility for saving their people.

The double-barrelled effect of Islamic and adat teachings about the need to protect young women, to seclude young women at night-time and the responsibility of young women to protect their own and their families' reputation is the creation of an ideal of young womanhood which blends femininity with modesty, chastity, and responsibility.

In highland West Sumatra, the authorities' discourse of moral panic is both uniform and strong, buttressed by both Islam and adat, and made popular by the media. Among the authorities, alternative or critical discourses are rarely, if ever, heard. Only once or twice, in private to me, a parent suggested that the authorities were "coming down too hard" on young people: for instance, a Chinese man scoffed at the banning of the Valentine's Day celebration and 
a Minang woman complained at the (metaphoric) "morality police" who, she perceived, had forced her to wear an Islamic head-scarf, and were only concerned with the appearance of morality, rather than actual practice of morality.

To return to the term "moral panic", we can see that the panic in West Sumatra is much broader and more uniform than that in the UK. The discourse is not at all restricted to the media: it makes an impenetrable wall of sound. The moral panic is a productive discourse that identifies a crisis - the practice of pre-marital sex among young people - and produces a range of techniques to prevent that which has already been identified as happening. These techniques include government/Islamic regulations, teaching in mosques and schools, media panic, and family and community "protection" of young people (mainly young women). However, I have yet to see any evidence that the practice of pre-marital sex by young people in highland West Sumatra is widespread or growing. I turn now to the perceptions and behaviours of young people themselves.

\section{YOUNG PEOPLE'S PERCEPTIONS, ATTITUDES, AND BEHAVIOUR}

My research team designed and implemented a survey of 3,565 teenagers (median age 16) in nine provinces around the country. One of the questions in our survey was: "According to you, what problems do youth face today? (Please mention three)." As this was an open-ended question, we were very surprised by the dominance of a fairly unified response. If we just look at the first of the three possible answers each respondent could supply, free sex (seks bebas) or free socializing (pergaulan bebas) was the answer in 50 per cent of the surveys. If we look at the second of the three answers, this answer crops up in another 27 per cent of the surveys. So over three-quarters of all young people surveyed considered that free sex or free socializing are problems that Indonesian youth face today. Further, there was a gender pattern to these answers: looking at the first answers, 45 per cent of boys and 54 per cent of girls nominated seks bebas or pergaulan bebas. Boys showed more concern than girls about drugs, smoking, and alcohol consumption, but the figures were not high (15 per cent of boys and 8 per cent of girls).

Comparative study of the survey statistics showed, unsurprisingly, that the concern with seks bebas and pergaulan bebas was strongest in West Sumatra, with a more exaggerated gender pattern: 55 per cent of the respondents wrote seks bebas and/or pergaulan bebas as the first problem, with 46 per cent of boys and 62 per cent of girls answering in this way.

I collected hundreds of essays from students at a senior high school. Typically I would obtain the consent of the teacher before the lesson, and ask the class to write an essay on one of five set topics. Sometimes the essays were written as homework, and sometimes during class. By far the most popular essay topic was "The problems faced by Minang young people". The standard claims were that the morals of young people were "lacking" or "rotting, in decline", and that "the cultural forms of foreign cultures - among them, free 
socializing, tight clothing, narcotics, and strong drink" - were "cutting down" or corrupting the morals of the young. ${ }^{3}$

Sometimes these claims were couched in terms of conflicts with the norms of Minangkabau adat and Islam, and sometimes as a betrayal of the high morality set out by the forefathers - the Minangkabau national heroes and pioneers such as former Vice President Mohammad Hatta. Most students explicitly linked the decline in morals to the negative influence of the West and globalization, and posited a causal link between lack of parental attention, the negative influence of Western media and inadequate keimaman (religious commitment) on the one hand and undesirable practices such as wearing tight clothing and showing one's aurat, free sex, drug abuse and criminal behaviour (such as rape) on the other. Almost all mentioned the issue of tight clothing and of "showing the aurat". ${ }^{4}$ The solution was invariably to strengthen religious commitment and to build a moral fortress against the negative incursions of the West through a revived adat, and for young women to choose the right path of modest dress, polite language and proper respect.

In a blog entitled "Don't abandon Minang culture", one young woman wrote:

I strongly disagree with the modernization that obliterates Minangkabau culture. Minangkabau adat is an Eastern adat that is thick with religion: Adat basandi syarak, syarak basandi kitabullah (adat is based on Islamic law and Islamic law is based on the Qur'an). This means that if young people don't have any feelings of love for our culture in ranah Minang, then we youth are a generation without culture. We must defend Minangkabau culture [...] (Essy 2007).

Thus, unsurprisingly, these essays reproduced faithfully the discourse of moral panic purveyed by the authorities, and seemed to show that our survey results were valid. I was still sceptical, not least because the discourse of school essays does not necessarily echo young people's everyday opinions or behaviour. I set out to find "naughty" (nakal) young people: I attended pop concerts; I snooped in cafés, comics libraries, warnet (internet cafés), parks, and other hangout spots; I "hung out" on Saturday nights, at the town square; I spent a month talking to young people in kos (boarding houses). I even let it be known that I wanted to talk to people who had had "shotgun" weddings, and this led to a couple of embarrassing situations.

Gradually, through interviews, friendships, and observations, I came to the conclusion that most young people of school age indeed firmly believe that

3 The quotations in this sentence and later are from one unexceptional essay by a student in the penultimate year of a top state academic school.

4 Aurat is a complex Arabic term that refers to that area of the body that should be covered in public. Aurat is often translated as "nakedness". It is a word used in the Qur' an and in Islamic writings worldwide. In mosques and Islamic schools in West Sumatra, congregations are exhorted to "Tutuplah auratmu!" (Cover your aurat!). Minang girls and others emphasize that the chief function of the jilbab is to enable women to obey this injunction. As one female student said, "The jilbab is something for covering the aurat so that females will not be too much seen by guys or anyone." 
pre-marital sex is wrong, that the morals of society are in decline because of the pernicious influence of the West, and that Minang identity is threatened by deviant behaviour, such as free socializing. ${ }^{5}$ Furthermore, there are actually few opportunities of time and place for "naughty" sexual behaviour: most young women are very busy with both school and les (private tutorial classes, held in the afternoons), and are grateful to have a day at home on Sundays to rest and help out at home, and of course they are not allowed out at night. This busy schedule and tight rein is somewhat classed: middle class girls who attend public "academic" schools and madrasah" are generally much more constricted than working class girls at vocational schools, and girls at pesantren ${ }^{7}$ have no opportunity to roam (Parker 2009). Most schoolgirls had never slept over at girlfriends' houses. Boys are allowed more rope. There is also the problem of where a couple can actually be a couple: it's risky to walk the streets hand-in-hand or even just as a twosome; no-one has access to a car; and it's unthinkable to ask a boy/girlfriend to one's home. The dark insides of cafés are probably the best bet. Most boy/girlfriend couples meet within groups. For instance, a group of girls would meet a group of boys at the park or in a café and socialize, accompanied by much laughter and teasing, within the larger mixed-sex group.

Nevertheless, there were individuals who stood out for their transgressive "free" behaviour. We came to think of a continuum, with most young people at one end, the "good girl (or boy)" end, a good number of young people strung along the middle section, marked by having or approving the idea of boy/ girlfriends, and a small minority at the other end, marked by "bad boy (or girl)" behaviour, such as running around town, truanting, smoking, drinking, (possibly) having sex, or at least "approaching zina (sexual intercourse outside marriage)".

\section{APPROACHING ZINA}

Suzie, a student at a private tourism vocational school, was the only girl I came across who had two boyfriends (pacar) simultaneously. She claimed that she had had a boyfriend since her second year of junior high, which made her the most precocious girl I knew. She said of boyfriends: "It's normal for teenagers [...]. You can be $100 \%$ open to a boyfriend." Suzie was quite brazen in her behaviour, and said she would hold hands with a boy. (Many other teenagers considered that holding hands was already on the slippery slope to pre-marital sex, and were stridently critical of such behaviour.) But Suzie's boyfriends were a problem for her girlfriends, and for her reputation,

5 In this paper, I follow my research participants in taking sexuality as heterosexuality. Among school-age teenage girls, heterosexuality was hegemonic; some older boys had heard about "homo" and "gay". My assessment follows Boellstorff's conclusions (2005: 68, 70-71, 94, 100 ), that knowledge of the possibility of alternative sexuality usually comes via discovery of the idea of same-sex attraction in the mass media, such as in magazines, and recognition that that concept fits oneself, usually in the late teens or early twenties.

State Islamic school

Islamic boarding school 
because her relatively autonomous boyfriend behaviour was interpreted by her girlfriends as transgressive and promiscuous. In fact, her friends at school were telling her secrets beyond their circle, enhancing their own social capital through gossip about Suzie. When young women violate social norms of ideal femininity, sexual deviance is often imputed to them, regardless of the facts. When I asked Suzie, "What is the most serious problem that you face at the moment?" She answered: "The problem of girlfriends and boyfriends. I have three friends, and I'm trying to explain to them that I'm not as bad as they think because of my boyfriends."

Boyfriends are often kept secret from parents. Friends of the girl are often the most obvious troublesome obstacle to having a boyfriend. Sometimes the friends are jealous of the time and attention directed to a boyfriend, but often it is the puritan morality and concern of friends that kicks in: they are worried that their friend will do herself damage by having a boyfriend - in the form of lower grades at school or a damaged reputation.

However, even Suzie draws the line at pre-marital sex, referring to the notion of zina. Zina is a major sin in Islam and includes pre- and extra-marital sex. All Minang young people that I interviewed viewed premarital sex as zina. Some consider that sexual behaviour that "approaches" zina, such as holding hands, are "the same as having sex" - they constitute zina.

Sari, another student at a private vocational school, had had a boyfriend for seven months, but had not yet told her parents. She was too scared. She said, "In my family, if you want to have a pacar, you have to have graduated from school first, finish school first." She said they seldom meet and mainly communicate by telephone and through SMSs. I asked whether they held hands, and she said no, "For the people around my place, adat is really strong. They really hold on to adat. Moreover, I'm a girl." This comment reflects hierarchies of sexual conservatism of both gender and place. Girls are more vulnerable to stains on their reputation than boys. The city (say Padang or Jakarta) is "sin city", where anything goes; a town in the highlands is seen as much more conservative; and the rural village or kampong is seen as the most conservative place. Sari thought that holding holds was OK, but "[D]on't do it in public. Holding hands - I'd feel embarrassed if someone saw me. People, they'd see me as a bad girl." Like other girls in this group, she thought holding hands was OK; hugging was worse - if seen in public it would "ruin one's image and that of one's family"; and kissing was "already sex". Having a pacar is not automatically a status symbol as it is, for example, among Australian high school students.

\section{BERPACARAN (HAVING A BOY/GIRLFRIEND)}

The age at first marriage for young women in West Sumatra was already over 25 years in 1990,8 and the median ideal age of marriage among respondents in

$8 \quad$ Hull 2002: 11, Table 2. The same trend is noted by Blackwood (2000: 87) for the rural village where she worked: the age at first marriage for women born in the 1920s and 1930s was 17.5 years and was 19 years for those born in the 1950s and 1960s. 
our survey for this town was 25 years. Most young people of school age - boys as well as girls - hold that while they are in school, they should focus on study and not have a pacar. A standard answer to questions about whether or not one has a pacar is that one should "study first". It is common to hear this even at university. Even the transgressive Sari noted this aphorism. Nevertheless, having a boy/girlfriend is considered fairly normal at non-religious schools - though the relationship is often not very serious.

Poppy is a bright young student at one of the best public schools, and she aspires to a career in psychology. She has already had one boyfriend, but she said they had never gone out just the two of them. When I asked her what she considers the most important problem faced by Minang adolescent girls now, she answered:

The problem of socializing. By socializing I mean where the child lives, the environment that will influence the child's way of learning/studying [...]. From there emerge problems of boyfriends, how she will face problems with her friends. Possibly, for now most problems for adolescents are to do with boy/girlfriends and free mixing. Possibly this is because of the influence of television. There are many sex scenes, the problem of kissing [...] I feel that the morals of teenage girls are very rotten [...]. Free sex is like the beginning of smoking: if smoking is already considered normal, then it develops into dope, then into tattooing, drinking, with drinking you don't realize it turns into drugs, continues on to kissing. If kissing is considered usual, how will it be with free sex? All that because of the influence of the environment. The influence of TV.

Poppy's representation of increasing momentum as "naughty" actions accumulate down the slippery slope that leads to premarital sex is a common one. Poppy was close to her mother, a pharmacist, and she was one of the few girls I knew who had known about menstruation before she had her first period. She was also the only girl who would admit to having seen a condom - at her mother's shop.

LP : What does your mother think about holding hands?

Poppy : Possibly Mama would explain by using verses from the Qur'an. The problem is that in the Holy Book we are not directed about boy/girlfriends. On the contrary, we are ordered to marry [...] Usually, it's the girl who will be seen, even though it's the guy who has ruined her - what guy? It's the girl, what's the public opinion of her? For sure, even though she might be clever, or rich, for sure in people's opinion she's already low, that girl can have no self-respect.

The instant recourse to an Islamic authority is typical of schoolgirls' discourse. Poppy is quite gender-sensitive and sees clearly the gendered double standard under which the guilt burden for illicit sexual behaviour is borne by the girl. Poppy implies that "holding hands" is behaviour that would "ruin" a girl. Poppy's one boyfriend experience might seem to indicate a female adolescence 
that is rebellious and independent, but on balance, her constant recourse to Islamic and adat sexual morality and her attitudes towards sexual practice are typical of Minang schoolgirls.

The issue of telling parents, or not, about a pacar looms large for most young people. Most young people presume opposition from parents, and aim for secrecy. However, as this conversation with a female student at an Islamic tertiary institute reveals, it is also not unusual for families to have a "policy" on pacar:

Before I graduated from high school, my brother didn't let me [have a boyfriend], but my mother let me, provided that I was careful. However, when I started here, I had three friends: [Friend 1], after she graduated from high school, she got married straight away because she had a boyfriend; then [Friend 2], she only had one semester of school and got married, so I thought, this would not be good for me, and my brother and family supported me in not having a boyfriend: better to prioritize my studies. So I think indeed there's no good in having a boyfriend there's nothing that has more negatives! So now I prefer not to have a boyfriend. ${ }^{9}$

As noted above, this is a town where it is very hard to hide if one wants to meet a boyfriend. Mobile phones, owned by two-thirds of our survey respondents in this town, are a pretty safe way to tee up meetings - this means that getting someone's mobile phone number is a little triumph that can set one on a path to getting a pacar. Apart from parental control, it often seemed that there was a deliberately-constructed structure that made it difficult for young people of different sex to get together. Couples in cafés usually try to hide down the back, away from the street. Most internet cafés in this town are unlike those in cities: there are no internal walls or cubicles, and the café looks more like a computer laboratory than the typical Indonesian warnet. (Interestingly, some warnet near schools advertise that they have installed a pornography filter, and some provide a prayer room.) Also, it is very hard to avoid gossip in a town like this. Girls in school are very concerned not to meet their teachers if they are not wearing their jilbab ${ }^{10}$ or if they are with a boyfriend. Female students often noted that if they had a boyfriend, the teachers would menyindir (mock or make fun of) them in class.

I hypothesized that it would be in kos (boarding houses) that I would find most "free socializing". However, in this town almost all kos are single-sex

9 One might argue that here is evidence of two "shotgun" weddings, a symptom of "free socializing". However, exhaustive enquiries and a search for shotgun weddings and youthful married couples turned up only two examples. In the first, the woman concerned had had to leave school precipitately, and get married with unseemly haste. In the other case, in a family familiar to the researcher, the "wild" young man, the bane of his family because he drank alcohol and would not keep at a job, was married with speed to a girl of "low" family whom they would not normally have approved. If there is a pre-marital pregnancy, the man must be made to marry the woman.

10 Most state schools in this town have decided to make the jilbab compulsory school uniform for girls. However, most of the vocational schools have not followed suit, making the class differentiation of girls highly visible. See Parker 2008. 
boarding houses with a strict curfew, usually the time of the magrib prayer, around sunset, and sometimes at nine p.m. Most kos are rooms in a family home, where the children have grown up and left empty bedrooms, or add-ons to the family home, as a business investment. Many kos are run by teachers, or are otherwise linked through the ibu kos (landlady) with the schools and colleges. When new students arrive from the country to find somewhere to live, the schools direct them to the ibu kos. In this way, most students living away from home are under double surveillance: at school and their kos, and if they play up in the kos, they will be reported at school. Ibu kos see their role as in loco parentis. One ibu kos, who runs a warung (small shop) and large rumah kos (boarding house) just near an Islamic school, used to teach at Diniyah Putri, a famous, long-established pesantren for girls (see Whalley 1993). She said she only takes students whose parents want her to supervise their children, and she has expelled students in the past because of them having pacar.

There are some interesting features of berpacaran. One is the thickening of interest in "the approach" - usually shortened to pdkt (pendekatan) - to the person with whom one has fallen in love. Here is how one student in a vocational school described a $p d k t$ in her diary:

In fact, it's really cool being friends with him. He pays a lot of attention to me. Almost every hour he sends me an SMS. At the very least, he only wants to say, good morning, good day, good evening, or sleep well. And he will definitely ask if I've already eaten or not. And even crazier. Now, in every SMS, he'll definitely say "honey" to me. You know, right, what honey means. Basically, it's really cool being friends with him.

In the event, that pdkt did not work, but she conveyed something of the excitement in receiving the attentions of a potential pacar through innocent SMS messages. A lot of "girl talk" is about the pdkt - what it means, is he serious, how to respond.

Jatuh cinta, or falling in love, is recognized as a real phenomenon experienced by teens in a heartfelt way, but interestingly, at this age, it is almost always seen as a relationship which is contingent and transient. It seems that falling in love is quite likely to lead to a "broken heart" (the English is used) - not to a lifelong marital partnership. Young women are almost in love with the idea of falling in love (see Nilan 2003). Falling in love is exciting and romantic, and many schoolgirls say that it would interfere with their schoolwork, so they had better not indulge.

Films, pop songs, novels, and magazines wax lyrical about the beauty of falling in love. The end of a relationship, "broken heart", is also much elaborated in pop songs and in magazines, and girls seem to accept that this miserable condition is unavoidable. The most common cause of tragedy is parental disapproval of the relationship, which usually means the relationship has to be terminated. Young women said that although arranged marriages were rare now, the approval of parents is a "must". The tension between love marriages and arranged marriages, and the troubles caused by unsuitable 
marriages (for instance, intra-clan marriages, inter-religious marriages, interclass marriages) are the staples of Minang folk stories and legends, and of the many important novels by Minang authors such as Hamka (for instance, Di bawah lindungan Ka'bah 'Under the protection of the Ka'bah'), Marah Rusli (especially Sitti Nurbaya), and Abdul Muis (Salah asuhan 'Wrong upbringing').

\section{GOOD GIRLS}

Many Minang Muslims take seriously the proscription against approaching zina, such as verse 34 of the Sura Isra (The Night Journey): "And approach not fornication (zina); surely it is an indecency and evil as a way." According to orthodox Islamic teachings, female adolescents may not be alone with any males who are not a muhrim, that is, the only males with whom an unmarried woman should consort (father, grandfathers, uncles, brothers, etcetera). Thus, female adolescents may not date, nor may they walk home from school with a boy. Annida magazine holds the line on this, arguing that a range of behaviours, including mailing letters, emailing, and SMSing to boy / girlfriends, "approaches zina".

Fitri, a day student at a state madrasah put it this way: "[O]ur religion, Islam, strongly forbids having a boy/girlfriend. There are many negative impacts. However we can, we must avoid having a boyfriend in order to keep our self-respect."

Fatima is another day student at a different madrasah. She says that religion "catches all of her life". She is very devout and espouses attitudes towards having a boyfriend that are not uncommon in religious schools:

According to me, ma'am, it's forbidden in law because, from what I studied when I was in Islamic junior high, a relationship of a male with a female without there being a tie [of kinship] is forbidden. That's zina in Islam, a major sin. It can be included as zina because looking with an intention that is not good, that is punishable as zina. For me, having a boyfriend, in Islam if you go out as a malefemale couple, there is a third who is Satan, ma'am. That Satan always orders humans to do things that aren't good. So, according to me, having a boyfriend is forbidden.

To me, the prohibition against having a boyfriend poses the practical problem of how a girl would ever find her jodoh 'eventual partner'.

LP : So if having a boyfriend is forbidden, how can you meet someone who could become your soulmate?

Fatima : In Islam the ones who marry you off are your parents, ma' am. It's best for a bride if she meets her soulmate exactly at the time she marries [...]. For sure my parents will choose what's best for me [...]. I will agree if I am married off by my parents because it's not possible for a parent not to want what's best for their child [...]. And if I am married off then I will feel very happy. I will feel that my parents care for me. 
Fitri answered the same question like this:

About jodoh, there are no human beings who really know - that is up to Allah. So we are certain that all people who have a boy/girlfriend do not yet know if that person is their jodoh-sometimes they could be boy/girlfriends for a year but still not know if they are the ones for marriage. That is proof that with regard to jodoh-identity it is not humankind that decides. So if looking for a jodoh, a woman's jodoh is guaranteed by the Qur' an and God, so if we want to marry, we are not forbidden from revealing this, but also only in a certain way, not directly. Because if a girl directly says, "I love you", that is like lowering the girl's power/ authority, because it's inappropriate that the one who asks is the girl. So if a girl wants to marry someone, she may express that but only in certain ways, like the girl says to her parents that she wants to marry, then her parents will look for someone for her. Certainly parents know better who would be suitable for their daughter. And indeed many now use looking for jodoh as an excuse for having a boyfriend. But how can that be for a kid who's just in SMP, can they really be ready for marriage? That is just an excuse for having a boyfriend.

The first time one of these girls earnestly explained how they would be quite happy for their parents to arrange their marriage, even to an unknown groom, I was quite shocked, but soon realized, from the number of similar responses, that arranged marriages are far from dead and gone in Indonesia, and that from the perspective of a 17-year-old, an arranged marriage partner is not necessarily terrifying (see also Smith-Hefner 2005 and Nilan 2008). Girls who live in the dormitories of Islamic schools have very little opportunity to have a pacar, and some are much more scared of the prospect of their own inexperienced and potentially unwise choice of a stranger than they are of the husband selected by their parents, who are presumed to have their daughter's interests at heart.

\section{CONCLUSION}

The authorities' identification of "free sex" and "free socializing" as a problem rampant among youth in highland West Sumatra was actually not backed up with any evidence. And, indeed, young people themselves, while agreeing that "free sex" was a problem, did not generally see it as a problem for themselves. In other words, as in Poppy's little speech above, it was always other, unidentified young people who were susceptible to the "threat". Of course, in this puritan environment, it would only be a very foolhardy young woman who would hold hands with a boyfriend, let alone admit to engaging in pre-marital sex. Anyone who was serious about a pre-marital sexual romance would be well advised to leave town.

One could make a convincing case that there was indeed no moral crisis or threat. Certainly, the characterization of the "moral panic" as "out of all proportion to the actual threat offered" (Hall et al. 1978:16) seems applicable. It may be that the strength of the morality discourse was such that any "deviant" or "devil" had physically left town, leaving the moral authorities to wield discursive power unopposed. Certainly, I knew people who were 
not Muslims who had left town largely because of the Islamization of public space and educational institutions (like compulsory jilbab as school uniform). In Padang and Jakarta, I knew young adults working, looking for work, and studying at university, who decried the heightened intolerance and increasing restrictions on social interaction in West Sumatra; some of them went to some lengths to hide their actual social practice from family and community back in highland Sumatra. Some vowed they would never return. It seems a shame that the historical openness and vibrancy of Minangkabau culture seems to becoming increasingly closed and inward-looking.

Many young people in West Sumatra enjoy Western pop, rock, and other popular music, and many love American movies. However, the overwhelming discourse of young people in West Sumatra is that of moral panic and social conservatism: young people believe that sex outside marriage is a sin; they believe that the moral influence of the West is pernicious, and they believe that marriage is the ideal "protection" against the temptations of "free socializing". It seems to this outside observer, that the fiction of fear and threat renders young women as vulnerable objects of male sexual desire, in need of protection. The main threat actually seems to be the threat of gossip and innuendo - that is, a threat to reputation and hence marriageability. An appropriate marriage and the position of women have long been the two most potent seams of fracture in Minang society, as recorded in the famous love story by Minang author, Marah Rusli, Sitti Nurbaja.

Viewed from afar, highland West Sumatra now seems like a moral fortress. The moral panic certainly triggered a response from the authorities: they banned innocent entertainments and enacted syariah-like regulations that set them up as the moral authorities and "naturalized" their power. One wonders how their declaration of moral crisis resonates with their "wider anxieties" (Cohen 2004: xxx) and sentiments of "ambivalence" and "unconscious guilt" (Garland 2008: 15). At a time of decentralization, democratization, and liberalization, the authorities have perhaps been emboldened to shift their guilt over corruption and overweening power, their ambivalent enjoyment of Western media and entertainments, and their anxiety over some of the pressure points in Minangkabau society onto young people.

\section{REFERENCES}

Amir M.S. 2007. Masyarakat adat Minangkabau terancam punah. Jakarta: Mutiara Sumber Widya.

Bachyul, Syofiardi. 2008. "Valentine's celebrations banned in Bukittinggi", The Jakarta Post, 14 February. [Http://www.thejakartapost.com/ news/2008/02/14 /valentine039s-celebrations-banned-bukittinggi.html, accessed on 14-3-2012.]

Blackwood, E. 2000. Webs of power; Women, kin, and community in a Sumatran village. Lanham, Maryland: Rowman and Littlefield.

Cohen, S. 1972. Folk devils and moral panics; The creation of the Mods and Rockers. Oxford: Martin Robertson. 
Cohen, S. 2004. Folk devils and moral panics. Third edition. London: Routledge. Essy. 2007. "Jangan tinggalkan budaya Minangkabau”, Just another window of Ikatan Uda Uni Kota Padang, 23 November. [Http:/ / iuukp.wordpress. com/ 2007/11/23/jangan-tinggalkan-budaya-minangkabau/, accessed on 29-8-2012.]

Garland, David. 2008. "On the concept of moral panic", Crime Media Culture 4(1): 9-30.

Hall, S. et al. 1978. Policing the crisis. London: Macmillan.

Handajani, Suzie. 2005. "Globalizing local girls; The representation of adolescents in Indonesian female teen magazines". Master thesis, The University of Western Australia.

Harding, Claire. 2008. "The influence of the 'decadent West'; Discourses of the mass media on youth sexuality in Indonesia", Intersections; Gender and Sexuality in Asia and the Pacific, Issue 18, October. [Http://intersections. anu.edu.au/issue18/ harding.htm\#n12, accessed on 14-3-2012.]

Herwandi (ed.). 2007. Kebijakan setengah hati dan kerisauan tentang degradasi kebudayaan Minangkabau. Padang: Pusat Studi Humaniora, Panitia Peringatan 25 Tahun Fakultas Sastra, Universitas Andalas.

Hooker, M.B. 2008. Indonesian Syariah; Defining a national school of Islamic law. Singapore: ISEAS Publishing.

Hull, T.H. 2002. "The marriage revolution in Indonesia". Paper Conference of the Population Association of America, Atlanta, 9-11 May.

Kailani, Najib. 2010. "Muslimising Indonesian youths; The Tarbiyah moral and cultural movement in contemporary Indonesia," in: Ahmad-Norma Permata and Najib Kailani (eds), Islam and the 2009 Indonesian elections, political and cultural issues; The case of the Prosperous Justice Party (PKS), pp. 71-96. Bangkok: IRASEC. [Occasional Paper No. 12.]

McRobbie, Angela and Sarah L. Thornton. 1995. "Rethinking 'moral panic' for multi-mediated social worlds", The British Journal of Sociology 46(4): 559-574.

Naim, Mochtar. 2006. Tiga menguak tabir; Perempuan Minangkabau di persimpangan jalan. Padang: Hasanah.

Nilan, P. 2003. "Romance magazines, television soap operas, and young Indonesian women", Review of Indonesian and Malaysian Affairs 37(1): 45-70.

Nilan, P. 2008. "Youth transitions to urban, middle-class marriage in Indonesia; Faith, family, and finances", Journal of Youth Studies 11(1): 65-82.

Noerdin, E. 2002. "Customary institutions, syariah law, and the marginalisation of Indonesian women," in: K. Robinson and S. Bessell (eds), Women in Indonesia; Gender, equity, and development, pp. 179-186. Singapore: Institute of Southeast Asian Studies.

Padang Ekspres. 2012. "Valentine Day, 17 orang dijaring", 16 February. [Http:/ / padangekspres.co.id/?news=berita\&id=23911, accessed on 30-8-2012.]

Parker, Lyn. 2008. “To cover the aurat; Veiling, sexual morality, and agency among the Muslim Minangkabau, Indonesia", Intersections; Gender and Sexuality in Asia and the Pacific 16, pp. approx 5-20. [Http:/ / intersections. anu.edu.au/issue16/parker.htm.] 
Parker, Lyn. 2009. “Religion, class and schooled sexuality among Minangkabau teenage girls", Bijdragen tot de Taal-, Land- en Volkenkunde 165(1): 62-94.

Putra, Y.S. (ed.). 2007. Minangkabau di persimpangan generasi. Padang: Fakultas Sastra, Universitas Andalas.

Singgalang. 2004. "Di Solok, kondom ditemukan dalam tas siswa", 28 September. [Http:/ / www.hariansinggalang.co.id/sgl.php? module=detailberita\&id=285, accessed 1-11-2011, no longer available.]

Singgalang. 2010. “HASIL SURVEI KRR: 63 persen remaja pernah berhubungan seks", 30 July. [Http:/ / www.hariansinggalang.co.id/sgl.php?module=detail berita\&id=285, accessed on 1-11-2011, no longer available.]

Smith-Hefner, Nancy. 2005. "The new Muslim romance; Changing patterns of courtship and marriage among educated Javanese youth", Journal of Southeast Asian Studies 36(3): 441-59.

Whalley, L.A. 1993. Virtuous women, productive citizens; Negotiating tradition, Islam, and modernity in Minangkabau, Indonesia. PhD thesis, University of Illinois, Urbana-Champaign. 